\title{
Immigration Law and Policy of Japan in the Age of East Asian Community- Building*
}

\section{Yoshiaki Sato **}

Japanese immigration law has been amended several times since 2000. These revisions aimed at coping with globalization and regionalization in East Asia. Since mobility is a critical issue for establishing a transnational labor market and ultimately a regional community, this article examines the interaction between Japanese immigration law, especially that of the Industrial Training and Technical Internship Program, and the struggle to build an East Asian Community. This article proposes enhancing the mutual recognition of certifications of skill as a means to promote the movement of people in the region.

\section{Keywords}

Immigration law, Mobility, East Asian Community, Industrial Training and Technical Internship Program, Mutual Recognition of Certifications

\section{Introduction}

Japanese immigration law has been frequently amended since 2000. The Immigration Control and Refugee Recognition Act ${ }^{1}$ was revised in 2001, 2004, 2005, 2006 and 2009. The overall trend has been providing immigrants with greater access to the Japanese labor market. The Tourism Nation Promotion Basic Plan 2 and the New Growth Strategy

* This paper was presented at the East Asian Legal Studies Lunchtime Talk held at Harvard Law School on March 22, 2010. The author is grateful to Keisuke Mark Abe, Young Hill Liew and Mark Ramseyer for their valuable comments.

** Professor of Law, Seikei University, Japan; Intellectual Member, Council on East Asian Community. LL.B., LL.M., Ph.D. (Tokyo). The author may be contacted at: sato@law.seikei.ac.jp /Address: Faculty of Law, Seikei University, 3-31 Kichijoji-Kitamachi, Musashino, Tokyo, 180-8633, Japan.

1 Available at http://www.moj.go.jp/ENGLISH/information/icrr-01.html (last visited on Oct. 4, 2010).

2 Available at http://www.mlit.go.jp/kankocho/en/vision/plan.html (last visited on Oct. 4, 2010). 
(Basic Policy) $)^{3}$ enumerated various measures to increase visitors to Japan. For example, the latter declared an annual target of 25,000,000 visitors - tourists as well as immigrants, to Japan by 2020,4 from $7,711,828$ in 2008.5 In particular, the Japanese government has attempted to increase the number of 'students' to 300,000 by 2020.6 In 2008, 138,514 college students, including undergraduate and graduate, and 41,313 precollege students, vocational and language students, stayed in Japan.7 Additionally, Japan removed a ban on Chinese group-tours in 2000 and individual-tour of Chinese in 2009. Furthermore, Japan is planning to relax the annual income requirement with regard to Chinese tourist visas, which is 250,000 Chinese Yuan.

The amendments were prompted by the needs to cope with globalization and the regionalization of East Asia. For example, the 2005 amendment was prepared for the ratification of the Protocol to Prevent, Suppress and Punish Trafficking in Persons, Especially Women and Children, Supplementing the United Nations Convention against Transnational Organized Crime. 8 The amended Article 5, paragraph 1, item 7-2 of the Immigration Control Act stipulates that "a person who has committed trafficking in person shall be denied entry to Japan." 9 "Trafficking in persons" is not specifically defined in any Japanese statute. Japanese courts refer the definition by the Protocol to Prevent, Suppress and Punish Trafficking in Persons, a ratified international agreement. Article 3, paragraph 1 of the abovementioned Protocol defines "trafficking in persons"

3 This is the cabinet decision made on December 30, 2009, available at http://www.kantei.go.jp/foreign/topics/2009/ 1230strategy_image_e.pdf (last visited on Oct. 4, 2010).

4 Supra note 2, at 5.

5 Immigration Bureau, Ministry of Justice of JaPAn, 2009 Immigration Control 2 (2009).

6 Monbukagakusyo et al., Ryugakusei 30 Man-Nin Keikaku, Kosshi (July 29, 2008), http://www.kantei.go.jp/jp/ tyoukanpress/rireki/2008/07/29kossi.pdf (last visited on Oct. 4, 2010; available only in Japanese). The 2009 reform of the Immigration Control Act created a resident status of 'student' consisted of the former 'college student' and 'pre-college student.'

7 Supra note 5 , at 24 .

8 G.A. Res. 55/25, annex II, U.N.GAOR 55th Sess., Supp. No. 49, at 60, U.N. Doc. A45/49 (vol. I) (2001), available at http://www.unodc.org/pdf/crime/a_res_55/res5525e.pdf (last visited on Oct. 1, 2010). Japan has not ratified the International Convention on the Protection of the Rights of All Migrant Workers and Members of Their Families, Dec. 18, 1990,.

9 Other revisions concerning the prevention of trafficking in persons can be found in Article 5, paragraph 1, item 7-2 concerning the prevention of the trafficking in persons and Article 50, paragraph 1, item 3 concerning the special permission to stay for victims of trafficking in persons. Japan also revised its Penal Code, Law for Punishment of Organized Crimes, Control of Crime Proceeds and Other Matters. The National Police University started to give lectures on trafficking in persons. These measures were taken in accordance with Japan's Action Plan of Measures to Combat Trafficking in Persons, released on December 7, 2004, available at http://www.mofa.go.jp/policy/ i_crime/people/action.pdf (last visited on Oct. 5, 2010). It is pointed out that 'significant improvements' in the prosecution of trafficking offenders can be observed. See U.S. Department of States, 2007 Country Reports on Human Rights Practices, available at http://www.state.gov/g/drl/rls/hrrpt/2007/100522.htm (last visited on Oct. 5, 2010). For details on human trafficking in Japan, see Yasuzo Kitamura, Evolution of Antitrafficking in Persons Law and Practice in Japan: A Historical Perspective, 14 TuL. J. INT'L \& COMP. L. 331 (2006). 
as "the recruitment, transportation, transfer, harboring or receipt of persons, by means of the threat or use of force or other forms of coercion, of abduction, of fraud, of deception, of the abuse of power or of a position of vulnerability or of the giving or receiving of payments or benefits to achieve the consent of a person having control over another person, for the purpose of exploitation." 10 Exploitation includes "forced labor or services, slavery or practices similar to slavery, servitude." 11 Another amendment promulgated in 2006 aimed at fortifying the country's defenses against terrorists.

The most recent amendments, which came into force on July 1, 2010, is to prevent abuses of the Industrial Training and the Technical Internship Program. The Industrial Training and the Technical Internship Program of Japan is the largest scheme in the world for an individual country to assist capacity building of people in the neighboring countries. 12 The Industrial Training Program originated in the 1960's when the government permitted some companies to invite employees of their foreign subsidiaries to train for up to one year at the parent company in Japan. In 1993, the government allowed for intra-industrial associations of small or middle-sized companies to arrange the interns for host companies and added the Technical Internship Program, which enabled the trainees to continue learning two more years.

These flexible rules have naturally led to an increase in the number of trainees and interns. In 2008, 101,879 trainees and about 105,000 interns were residing in Japan.13 This figure is almost the same as that of the all employment-based residents (excluding diplomats and government officials) 14 and students. More than 18,514 companies accepted trainees in 2009.15 The overwhelming majority came from East Asian nations, nearly 80 percent of Chinese nationals. 16

The Industrial Training Program has contributed to the development of human resources, as well as quality control and production management in participating

10 Article 226-2, paragraph 5 of the Penal Code stipulated: "[a] person who sells or buys another for the purpose of transporting him/her from one country to another country shall be punished by imprisonment with work for not less than 2 years," available at http://www.cas.go.jp/jp/seisaku/hourei/data/PC_2.pdf (last visited on Oct. 4, 2010).

11 Id.

12 Yoshiaki Sato, The Industrial Training Program and the Technical Internship Program of Japan: A Means for Transferring Technology or a Disguised Guest Worker Program?, 68-69 SEIKEI HoGAKU 21, 28-36 (2008).

13 See e.g. Japan International Training Cooperation Organization, Industrial Training and Technical Internship PRogram Implementation Report: JITCO White PAPER FY 88, 128 (2009).

14 In 2008, 214,230 foreigners were eligible to work in Japan as highly skilled workers with permission of specified occupations, except diplomats and government officials. See supra note 5, at 24 . If long-term residents, such as 'Nikkei-jin,' and permanent residents, such as spouses of Japanese nationals and former nationals were included, the figure would be 562,818 workers in 95,294 places of employment. See Masahiko Yamada, The Current Issues on Foreign Workers in Japan, 7-3 JAPAN LABOR REv. 5 , 9 (2010).

15 Supra note 14, at 97 (this number stands for the number of accepting companies supported by the Japan International Training Cooperation Organization, "JITCO").

16 Id. at $85,114$. 
countries. 17 However, serious abuses have been reported. For example, the International Covenant on Civil and Political Rights ("ICCPR") Human Rights Committee expressed concern over the exploitation and exclusion of trainees from the protection of domestic labor and social security laws.18 The Committee recommended that the Japanese government consider replacing the current Industrial Training Program with a new scheme that adequately protects the rights of trainees and interns and focuses on capacity building rather than recruiting low-cost labor.19 The Trafficking in Persons Report of 2010 published by the U.S. Department of State also found mistreatment of foreign workers, including fraudulent terms of employment, restrictions on movement, withholding of salary payments and debt bondage, [and] [t]rainees sometimes had their travel documents taken from them and their movement controlled to prevent escape. 20 Against these international criticisms, the Japanese government sanctioned revisions in 2009. In addition, because most interns are coming from East Asia, preparation for the integration of East Asia is another reason to amend the program.

Therefore, Japanese lawmakers should recognize the regional impact and implications of legislation than ever before. This paper focuses on the interaction between Japanese law and international law, which have traditionally been regarded as separate and distinctive systems. Section 2 overviews the recent developments that have taken place in the areas of community-building in East Asia. Finally, in section 3, the latest reform of Japanese immigration law will be considered.

\section{Community-Building in East Asia and Movement of Persons}

The history of diplomatic talks on regional integration and community-building in East

17 Hiroaki Watanabe, Concerning revisions in the Foreign Trainee and Technical Intern System, 7-3 JAPAN LABOR REV. 43, 48 (2010).

18 See Consideration of Reports Submitted by States Parties Under Article 40 of the Covenant, Concluding Observations of the Human Rights Committee: Japan, U.N. Doc. CCPR/C/JPN/CO/5, 7-8 (2008) (pointing out that these workers "are often exploited in unskilled labour without paid leave, receive training allowances below the legal minimum wage, are forced to work overtime without compensation and are often deprived of their passports by their employers.")

19 Id.

20 U.S. Department of State, Trafficking in Persons Report 2010, 189-90 (noting that "the government did not exhibit efforts to adequately monitor and regulate its foreign trainee program, and has never criminally investigated, prosecuted, or convicted offenders of labor trafficking in the program"). In the Human Rights Reports of 2002, the U.S. Department of State considered the Industrial Training and Technical Internship Program as an 'exploitative practice.' See U.S. Department of State, 2002 Human Rights Report: Japan, available at http://www.state.gov/g/drl/ $\mathrm{rls} / \mathrm{hrrpt} / 2002 / 18246 . \mathrm{htm}$ (last visited on Oct. 5 , 2010). See also infra note 50. 
Asia can be understood as having three phases. The first phase was from 1997 to 1998, when East Asian countries strived to overcome the financial crisis that originated in Thailand and overwhelmed all East Asia. Prime Minister Mahathir bin Mohamad of Malaysia proposed establishing an East Asian Economic Caucus. ${ }^{21}$ Some nations, including Japan gave their assent to the scheme. Due to the strong opposition by the United States and the International Monetary Fund, however, this idea has never been realized. Instead, East Asian countries organized a financial dialogue leading to the Chiang Mai Initiative, a regional network of bilateral currency swap arrangements. Based on the Initiative, for the first time, the East Asian region emerged as a unit.

The second phase went from 1999 to 2002. In 1999, the Association of South-East Asian Nations ("ASEAN") plus Three ("APT") Summit issued a statement in order to strengthen their mutual cooperation for the first time.22 Following the suggestion of President Kim Dae Jung of Korea, the summit established a track-two group named the East Asian Vision Group ("EAVG"), composed not only of governmental officials, but also of scholars and business people. The EAVG was requested to submit a report on the means for establishing an "East Asian Community," a regime for comprehensive cooperation. ${ }^{23}$ Following the submission of the report by the EAVG,24 a track-one group, namely an intergovernmental group named the East Asian Study Group ("EASG"), examined the report of the EAVG and assembled its own report. 25 These two reports were published in 2001 and 2002, respectively. They recommended various short-term and long-term measures, including "a comprehensive human resources development program." 26 Thereafter, the APT countries implemented these recommendations one by one.

Japan took various actions pursuant to the recommendations in the reports. For example, the Council on East Asian Community ("CEAC") was inaugurated in 2004 as a platform of representatives of the Diet, governmental agencies, business corporations and academe. CEAC was established to serve as a country coordinator for the Network of East Asian Think-tanks ("NEAT"), a platform for track-two diplomacy.27 NEAT was

21 In 1990, Prime Minister Mahathir suggested this idea for the first time. See Yong Deng, Headless Dragons: The Problem of Leadership in APEC, 22 FLETCHER F. WoRLd AFF. 65, 72 (1998).

22 The summit was a top-level meeting of ten member states of the ASEAN, including: Brunei, Cambodia, Indonesia, Laos, Malaysia, Myanmar (Burma), the Philippines, Singapore, Thailand, Vietnam, plus China, Japan and Korea,

23 While a track-one process is a means for traditional international law-making, a track-two process might be evaluated as a way of cosmopolitan law-making. See Yoshiaki Sato, Towards the Institutionalization of Cosmopolitan Lawmaking, 46 ALBERTA L. REV. 1141, 1150-51 (2009).

24 The East Asian Vision Group ( “EAVG”), Report: Towards East Asian Community (2001).

25 Final Report of the East Asian Study Group, Nov. 4, 2002, available at http://www.mofa.go.jp/region/asiapaci/asean/pmv0211/report.pdf (last visited on Oct. 1, 2010).

26 Supra note 26, at 33-34. (recommending that the "comprehensive human resources development program" should focus on the improvement of ... skills training and capacity-building, including the establishment of a regional labor market information system). 
launched in 2003 by the initiative of China in accordance with the suggestion in these reports. It organizes several working groups which are expected to prepare reports on concrete measures to be taken for implementing the reports of EAVG and EASG. For instance, a Working Group on an East Asian Cooperative Framework for Migrant Labor, sponsored by Malaysia which is one of the large migrant worker-sending countries. 28 The Working Group published a report on December 7, 2006.29 Besides, Japanese scholars launched an international and interdisciplinary research project on East Asian Community. This research project, sponsored by the Institute of Social Sciences at the University of Tokyo, was completed in 2007 with a publication of a draft Charter of the East Asian Community. ${ }^{30}$ Article 19 of the draft Charter stipulates that, in paragraph 1, the Member States shall "reduce barriers to the free movement of nationals of the Member States who are carrying out trade in services within the Community," and, in paragraph 2, "promote the free movement of tourists, students and other shortterm visitors within the Community." The draft Charter continues to obligate the Member States to "cooperate to deal with illegal visitors in the Member States." 31

The third phase started after the publication of the final report of the EASG. In this period, the membership of the proposed Community was at issue. China prefers the APT model, while Japan and other states were for the "ASEAN plus Six," desiring to include Australia, India and New Zealand in order to maintain the balance of power in the region. In 2005, the latter countries succeeded in establishing the East Asian Summit ("EAS") consisted of ASEAN plus Six. In 2007, the ASEAN plus Three countries called APT as the main vehicle, and recognized and supported the mutually reinforcing and complementary roles of the APT and other regional fora including the EAS to promote the East Asian Community. 32 In 2009, the EAS reached an agreement on finishing track-

27 Besides NEAT, Korea took initiative to dispatch the East Asian Forum ("EAF"). While NEAT aims at promoting research, the EAF assembles representatives of various social sectors to have policy dialogues. A representative of ASEAN as a juridical person, usually the Deputy Secretary-General, also participates in the EAF.

28 Another East Asian country which is known for sending a lot of migrants is the Philippines. The inward remittance to the Philippines was $\$ 15,250,000,000$ in 2006 , which corresponds to $13 \%$ of the GDP. See The World Bank, Migration and Remittances Factbook 2008: Philippines, available at http://siteresources.worldbank.org/INTPROSPECTS /Resources/334934-1199807908806/Philippines.pdf (last visited on Oct. 5, 2010).

29 Network of East Asia Think Tanks, Regional Cooperation Framework for Migrant Labour, (Aug. 22, 2007), available at http://www.ceac.jp/e/pdf/neat_05wg05.pdf (last visited on Oct. 5, 2010). It is noted that much of the recommendations in the report were drawn from the ASEAN Declaration on the Protection and Promotion of the Rights of Migrant Workers, adopted on Jan. 13, 2007, available at http://www.aseansec.org/19264.htm (last visited on Oct. 5, 2010).

30 Tamio Nakamura (ED.), East Asian Regionalism from a Legal Perspective 256 (2009). The author was one of the four drafters mainly working out the chapters on institutional structures.

31 Id. at 263.

32 ASEAN plus Three Summit, Second Joint Statement on East Asia Cooperation Building on the Foundations of ASEAN Plus Three Cooperation, Nov. 20, 2007, available at http://www.aseansec.org/21099.htm (last visited on Sept. 28, 2010). 
two research about the Comprehensive Economic Partnership in East Asia ("CEPEA") and proceeding to intergovernmental negotiations. 33 In 2010, however, ASEAN countries decided to invite the United States and Russia to join the EAS. If the EAS expands to include these countries, it would stay as a forum for policy dialogue and would not become a community. Therefore, the APT seems to remain as the only platform for establishing a community.

It is still difficult to predict whether the East Asian Community will be established soon. East Asian community-building depends mainly on three countries in Northeast Asia. Although China, Japan and Korea concluded Economic Partnership Agreements ("EPAs") with ASEAN separately, they had not agreed to such treaties amongst each other. While historical antagonism from colonial actions of imperial Japan has been one of the obstacles to reaching an agreement, economic and security concerns, such as the protection of agricultural industries and food security of Japan, have also precluded agreement.

Another hindrance may be found in the lack of political leadership and pressure from a country outside of the regional community. 34 The United States, by declaring to start negotiations for accession to Trans-Pacific Strategic Economic Partnership Agreement ("TPP"), puts pressure on Japan and Korea not to build a regional Community with China because to the community would weaken the U.S. presence in the East Asian region. The TPP is one of the multilateral economic partnership agreements involving East Asian countries. Brunei, Chile, New Zealand and Singapore are member states. Australia, Peru and Vietnam already began negotiations to join the Agreement. It seems fair to say that Japan and many other countries in the region are realizing the possibility of the formation of a regional community. As such, the legal landscape of the relevant countries including Japan has undergone transformation in anticipation of a regional community, in particular with respect to immigration law.

33 See Chairman's Statement of the 4th East Asian Summit, Oct. 25, 2009, para. 19. In November 2009, Cambodia, Japan, Laos, Myanmar, Thailand and Vietnam launched the Japan-Mekong Summit. The participating countries declared that they would contribute to the establishment of the East Asian Community, as a long-term vision. See Tokyo Declaration of the First Meeting between the Heads of the Governments of Japan and the Mekong Region Countries, Nov. 7, 2009, available at http://www.mofa.go.jp/region/asia-paci/mekong/summit0911/declaration.html (last visited on Oct. 5, 2010).

34 Juliana W. Chen, Achieving Supreme Excellence: How China Is Using Agreements with ASEAN to Overcome Obstacles to Its Leadership in Asian Regional Integration, 7 CHI. J. INT'L L. 655, 656 (2007). In 2009, the Liberal Democratic Party, which was in power for about half a century in Japan, abruptly stepped down and the Democratic Party took control of the government. The new Prime Minister Hatoyama declared that he would promote a policy of establishment of the East Asian Community. However, Prime Minister Hatoyama resigned in June 2010, and his 'initiative' vanished. The disorders and lack of political leadership in Japan might be one of the reasons for China to emasculate the EAS. 


\section{Recent Changes in Japanese Immigration Law}

Movement of persons is always a significant issue in regional integration, which also made recent changes in Japanese immigration law. Three particularly notable examples should be examined. First, Japan has changed its policy with regard to refugees from traditional unwillingness to accept them. ${ }^{35}$ Japan has been passive, however, in recognizing people as refugees according to the Convention Relating to the Status of Refugees. 36

As such, Japan accepted mere 301 refugees from 1982 to 2002.37 Rather, Japan is accepting a substantial number of people by way of granting special permission to stay on humanitarian grounds. In 2009, Japan hosted more than 500 so-called refugees from 19 countries. 470 of them were granted special permission to stay, while only 30 from 8 countries were formally recognized as refugees. The number of people recognized as refugees is growing due to a 2005 amendment to the Japanese Immigration Control Act, which stipulates that the Ministry of Justice shall appoint about 20 refugee examination counselors who are to render an opinion when a claimant raises an objection to the denial of their refugee petition. 38 Another policy change, perhaps even more significant, is to accept refugees for resettlement. From 2010 to 2012, Japan plans for the first time to accommodate 90 people who have escaped from Myanmar and living in Thailand. As these displaced persons have come to attract much attention in Japan, the Japanese government seems to take further responsibilities for helping resettlement for refugees from East Asia.

Second, Japan has concluded economic partnership agreements with the Philippines and Indonesia to accept a number of workers from those countries for nurses or caregivers. Such workers will be allowed to stay in Japan for a period of three to four years. Upon passing the professional examination, which leads to the issuance of nurse or caregiver licenses for practicing in Japan, an applicant will be even eligible to apply for permanent resident status. ${ }^{39}$ In accordance with the Economic Partnership

Japan has funded the International Organization for Migration ("IOM") Voluntary Return and Reintegration Assistance Program which has been available since 2005. See U.N. Doc. A/Res/45/158 (Dec. 8, 1990).

36 Convention Relating to the Status of Refugees, July 28, 1951, 189 U.N.T.S. 150.

37 It is noted that, from 1978 to 2005, Japan received 11,319 people from Cambodia, Laos and Vietnam by special permission.

38 Some points remain to be improved. For example, the panel has to rely on data that was collected by refugee inquirers in the first screening process. Otherwise each counselor needs to make a judgment based on his knowledge. See Hiroshi Honma, Japan's Refugee Policy: From Post-World War II to Present Day, 18 Womer's Asia 21: VoICE FROM JAPAN 22, 24-25 (2007).

39 Although the Ministry of Justice retains discretion to deny the issuance of the permission, in normal case, the 
Agreement between Japan and the Philippines, 310 candidates were admitted to Japan in 2009 out of the maximum number of 500.40

A big policy change is that a nonimmigrant foreigner is generally permitted to stay and work in Japan in the following employment categories under the Immigration Control Act:

diplomats, government officials, professors, artists, religious workers, journalists, investors, business managers, legal and accounting professionals, medical service providers, researchers, instructors, engineers, specialists in the humanities/international services, intra-company transferees, entertainers, skilled laborers, 41 and designated activities under which the technical interns are permitted to work. 42

In principle, Japan maintains a policy to accept only highly-skilled workers in one of the above categories. The Fourth Basic Program continues this policy and sketches out a plan for establishing a point-based system for highly skilled foreign workers in order to promote their immigration. 43 Since unlicensed foreign nurses and caregivers are classified as semi-skilled, they were not permitted to immigrate prior to the Economic Partnership Agreement between Japan and the Indonesia. These kinds of agreements are significant steps to liberalize Japan's labor market, to bring in semi-skilled workers, and to further facilitate the movement of such workers within East Asia.

Finally, Japan has reformed its Industrial Training and Technical Internship Program in order to prevent its misuse. Trainees and interns are expected to learn skills that are difficult to acquire in their home countries. On the contrary to the Japanese government's goal to crack down on employment of illegal immigrants in the latter half of the 1990's,44 small or middle-sized companies turned to accept trainees and interns as

applicant would be granted permission. The Fourth Basic Program of Immigration Control, published in March of 2010, suggests the need to abolish the restriction for how long a nurse may stay. See Homusyo, Dai Yoji Syutsunyukoku Kanri Kihon Keikaku [The Fourth Basic Program of Immigration Control], Mar. 2010, at 18-19. The preceding Basic Plans were published in 1992, 2000 and 2005. The Fourth Basic Program is expected to be valid for five years. See id. at 2 .

40 According to the Economic Partnership Agreement between Japan and the Philippines, Japan would liberalize intracorporate transferees and short-term business visitors. Besides the EPAs, the Japan-China Junior Training Association commences to accept 200 Chinese nurses per year for training to get licensed in Japan. This project utilizes the framework of the Industrial Training and Technical Internship Program. See Japan-China Junior Training Association, Heisei 22 Nendo Jigyo-Keikaku, available at http://www.jpn-chn.or.jp/keikaku.html (last visited on Oct. 5, 2010).

41 For example, Thai cooks and artisans processing gems or fur are permitted to work under this category.

42 See Ministry of Justice Ordinance No. 16 (May 24, 1990) (as amended in 2010), available at http://www.cas.go.jp/jp /seisaku/hourei/data/mopcp.pdf (last visited on Oct. 5, 2010).

43 Supra note 39, at 17-18. Highly-skilled migrants had increased gradually from 2002 to 2007, but decreased in 2008.

44 Undocumented migration is a criminal act in Japan. See Immigration Control and Refugee Recognition Act, art. 70. In 1993, it is estimated that 298,646 illegal foreigners were living in Japan. See supra note 5, at 37. The government 
a substitute for illegal foreign labor workers. In other words, they utilized the Industrial Training and Internship Program as 'backdoor methods' of employing unskilled foreign workers. 45 The number of violations of relevant statutes and regulations by hosting companies increased from 92 to 452 between 2003 and 2008.46 The examples of mistreating foreign workers are included as follows: (1) double contracts, including secret clauses which stipulate penalties on interns for certain acts which cause inconvenience to the employee's agent or host company; (2) lending of name; (3) lack of overtime pay; (4) negligence in training employees; (5) disguised applications or inspection reports; (6) breach of labor laws; (7) confiscation of travel documents, including passports, to limit the employee's movement; and (8) forced deposit of the employee's wages. These mistreatments were mainly due to the law requiring the employee to be tied to a particular employer. Additionally, the inherently temporary nature of internships makes it difficult for an intern to enforce his or her legal rights after returning home. As noted above, the Industrial Training and Internship Program was severely criticized for these abuses; some even accused of being a tool for human trafficking. 47

The revised Immigration Control Act seeks to prevent the abuse by requiring intraindustrial associations, which is empowered to supervise host companies, to submit regular reports to the Ministry of Justice. Before the amendment, trainees were not covered by labor laws because they were not deemed 'employees.' 48 Since the new law has taken effect, interns should be recognized as employees from the beginning of the

has instituted tighter entertainer visa issuance for protecting migrant women from being forced to work in the sex industry. The government published the Action Plan for Achieving a Crime-Resistant Society in December 2003. See Ministerial Meeting Concerning Measures against Crime, Action Plan for Achieving a Crime-Resistant Society, available at http://www.npa.go.jp/english/seisaku8/action_plan.pdf (last visited on Oct. 5, 2010). The law proceeded to strengthen the control of immigration. As a result, the number of illegal foreign workers decreased to about 113,072 in 2008, almost one third of that of 15 years ago. See supra note 5, at 37. As of January 1, 2009, 2,561 extrainees had overstayed and become "illegal" immigrants. See supra note 5, at 38. In addition, 1,627 interns have absconded from their host companies. See supra note 14, at 130 .

45 The Program is said to be one of the 'backdoor methods' in order to alleviate shortages of home helpers. See Kazutoshi Koshiro, Does Japan Need Immigrants?, in Temporary Workers or Future Citizens? 151, 159 (Myron WEINER \& TADASHI HANAMI EDS., 1998).

46 Nyukoku-Kanrikyoku, Heisei 21 Nen No 'Fusei-Koui' Nintei Ni Tsuite(available only in Japanese), March, 2010, available at http://www.moj.go.jp/content/000033384.pdf (last visited on Oct. 5, 2010). On January 29, 2010, the Kumamoto District Court delivered a judgment, which required the accepting association and the host company to pay 17,250,000 yen to four interns. See AsAHI SimbUn 38 (Jan. 30, 2010) (available only in Japanese).

47 U.S. Department of State, 2008 Human Rights Report: Japan (pointing out that human trafficking in Japan remained a 'significant problem' ) available at http://www.state.gov/g/drl/rls/hrrpt/2008/eap/119041.htm (last visited on Oct. 5, 2010). See also Akira Hatate, The Distortion of the Foreign Trainee Program, 20 WoMEN's AsIA 21: VOICES FROM JAPAN 11 (2008) (asserting that "[i]t is no longer an exaggeration to say that the program has failed.").

48 A trainee could be recognized as a worker only when the trainee could succeed in proving that he or she had been working under the command of the host company. It is quite difficult to discharge the burden of proof. 
practical training, called on the job training, and all labor laws, including the Labor Standard Law and the Minimum Wage Act, shall apply to interns. In other words, the Labor Standard Inspection Office will have all the powers necessary to investigate and sanction violations of the laws, although the problem of enforcement remains an issue due to a shortage of workers at the Immigration and Labor Standard Inspection Department. 49 Other measures for protecting interns are as follows:

(1) providing lectures to interns about their legal rights;

(2) inspection of contracts between the intern and agency and denying entry when the contract contains illegal clauses (e.g., penalty clauses);

(3) monthly inspections of the host companies by the supervising association;

(4) supervision by the supervising associations of the accepting companies once in three months;

(5) providing advisors to interns; and

(6) establishing and increasing penalties to host companies and supervising associations for violating the new regulations, e.g., suspending the ability to sponsor new interns for five years. 50

Due to the escalation of aging population, the number of work force of Japan is decreasing fast. This process would be accelerated as a result of the declining birth rate. In 2006, there were 66,570,000 workers, and total labor population is estimated to go down to $61,800,000$ by 2030.51 On a way to solve this problem, there is a continuing controversy over immigration policies. Liberal Democratic Party recently suggested that the Industrial Training and Internship Program be abolished, as Korea had done. Instead, a 'guest worker' system, under which non-skilled foreign workers would be allowed to stay for three years, should be introduced. 52 The proponents for the 'guest worker' program are anxious that the social costs necessary for protecting and integrating migrant workers, especially for family reunification, would be too high. 53 In addition, they are concerned about the wage decline for Japanese workers. 54 The

49 The Immigration Office had only 3,413 inspectors as of 2008. See Houmusyo, Houmu-Nenkan Heisei 20 Nen 282 (2009). For details on the problem of enforcement, see Sumi Shin, Global Migration: The Impact of 'Newcomers' on Japanese Immigration and Labor Systems, 19 BERKELEY J. INT' L L. 265, 283-88 (2001).

50 Houmusyo Nyukoku-Kanrikyoku, Ginou Jisyusei No Nyukoku - Zairyu-Kanri Ni Kansuru Shishin [Guideline on the Control of Entry and Stay of the Technical Interns], Dec. 2009, at 31-32, 37.

51 National Institute of Population and Social Security Research, Population Statistics of JaPan 101 (2008).

52 See Jiyu-Minsyu-To Kokka-Senryaku Honbu Gaikokujin Roudousya Mondai PT, "Gaikokujin-Roudousya Tanki-SyurouSeido" No Sousetsu No Teigen [A Proposal for Establishing a Legal Framework to Accept Short-Term Foreign Workers], July 22, 2008, at 5-15.

53 Jiro Nakamura, Impacts of International Migration on the Labor Market in Japan, 7-3 JAPAN LABOR REV. 68, 74 (2010).

54 Id. (pointing out that, when 'Nikkei-jin,' foreign workers of Japanese ancestry, entered into a labor market, the wages of the Japanese male high school graduates working at the same place tend to decrease). 
Japanese Chamber of Commerce and Industry has not only proposed replacing the Industrial Training and Internship Program with a guest worker system, but also, in the long run, is considering a managed migration system under which Japan would be able to accept qualified non-skilled workers as permanent residents. 55 The proponents for opening Japan's borders point out the need to reform the Japanese industrial structure. However, increasing the number of unskilled foreign workers may help to preserve less productive sectors, i.e. labor-intensive and less competitive industries, while impeding the development of the industrial structure. ${ }^{56}$ Ultimately, human rights pressure and demographic realities will probably prevent Japan from taking this course. 57 It may be that Japan has little choice but to admit more permanent residents. 58 The Fourth Basic Plan does not set concrete measures and postpones the decision by saying that "discussion should be promoted regarding whether Japan should accept non-skilled migrant workers or not." 59

As long as the Japanese government cannot decide the best course of action, the Industrial Training and Internship Program seems to be the only means to meet needs of both the Japanese economy and the developing countries in East Asia which have a strong push factor for migration, redundant workers in rural part of the countries. The redundant workers seek their jobs not only in the cities of their own countries, but also in neighboring countries which are prosperous and have availability. 60 The demand for cheap, flexible workers who are willing to do even so-called 'Three-D' (Dirty, Degrading and Dangerous) jobs is a crucial pull factor in Japan since most Japanese are reluctant to engage in such.

The Industrial Training and Internship Program would establish a transnational labor market in East Asia, in which member States shall mutually recognize technical qualifications such as the APEC engineer system, etc.61 In fact, the NEAT Working

55 Nihon Syoko-Kaigisyo, Gaikokujin Roudousya No Ukeire No Arikata Ni Kansuru Yobo [A Request Concerning the Reception of the Foreign Labor], June 19, 2008, at 2.

56 Supra note 56, at 84 .

57 Demetrios G. Papademetriou \& Kimberly A. Hamilton, Reinventing JaPan: Immigration’s Role in Shaping Japan's FUTURE 63 (2000).

58 Carmel A. Morgan, Demographic Crisis in Japan: Why Japan Might Open Its Doors to Foreign Home Health-Care Aides, 10 PAC. RiM L. \& PoL’y J. 749, 779 (2001).

59 Supra note 39 , at 22-23.

60 The applicant for the internship is required to show that he or she is expected to engage in services that require the skills obtained in Japan after returning to his or her home country. See Ordinance of the Ministry of Justice No. 16 (May 24, 1990), as amended by Ordinance of the Ministry of Justice No. 43 (June 18, 2008).

61 APEC Engineer Coordinating Committee, The APEC Engineer Manual, July 2009. Japan has already recognized certain qualifications on information processing technology certified by East Asian countries. See Public Notice of the Ministry of Justice No. 579 of 2001, as amended by Public Notice of the Ministry of Justice No. 30 (Jan. 25, 2008). The Fourth Basic Plan suggested that Japan should promote the mutual recognition of the qualifications of engineers in not only the information processing technologies, but also other areas. See supra note 39, at 18. 
Group on an East Asian Cooperative Framework for Migrant Labor recommended that national laws of host countries be harmonized to ensure consistency throughout East Asia. 62 At the end of the first year, interns are obligated to take a certificate examination of basic grade 2 of the National Trade Skill Testing and Certification System. They may continue their internship only after passing the examination.63 As of July 1, 2009, examinations for 120 operations in 64 fields are identified for interns. 64 If these certifications are accepted by the countries sending workers, the existing Certification System may be a basis for a system of mutual recognition of certifications. In the end, a regional system of skills certification would be established.

\section{Conclusion}

It is hard to say when the idea of the East Asian Community would be materialized. 65 The amendment of Japanese immigration law, however, is trying to build an integrated labor market in East Asia through the Industrial Training and Technical Internship Program. This development is indicative. The movement of people is a most significant means for fermenting regional identity and integration that might lower the country barriers. It is of course true that the free movement in the global community causes a lot of complicated social, economic and political problems. However, as the process started by the Schengen Treaty shows, 66 these problems can be resolved effectively as long as member states are prepared to share the respective burdens. Already, potential member states of the East Asian Community have begun opening their borders gradually by changing their relevant domestic laws. Here, the author would suggest more researches to find ways of the interaction between municipal and international law towards regional integration.

62 Network of East Asia Think Tanks, supra note 30, at 3.

63 National Trade Skills Test system is based on the Human Resources Development Promotion Act. Most of the tests are classified into four grades, i.e. special, 1, 2, and 3, and others have a single grade. Basic Grade 1 and Basic Grade 2 are prepared specifically for foreign interns. See generally Japan Vocational Ability Development Association, Vocational Ability Evaluation System and Development and Implementation of Tests: National Trade Skill Testing \& Certification, available at http://www.javada.or.jp/english/pdf/e2_1.pdf (last visited on Oct. 5, 2010).

64 Supra note 14 , at 25-29.

65 As an example of the pessimistic view, see Tom Ginsburg, Eastphalia as the Perfection of Westphalia, 17 IND. J. GLOBAL LEG. STUD. 27, 37-38 (2010) (arguing that such a dynamic as promoted the grand bargain between France and Germany to launch the community-building in Europe is, at present, unthinkable between China and Japan).

66 Schengen Agreement 1990, 30 I.L.M. 68(1991). 
